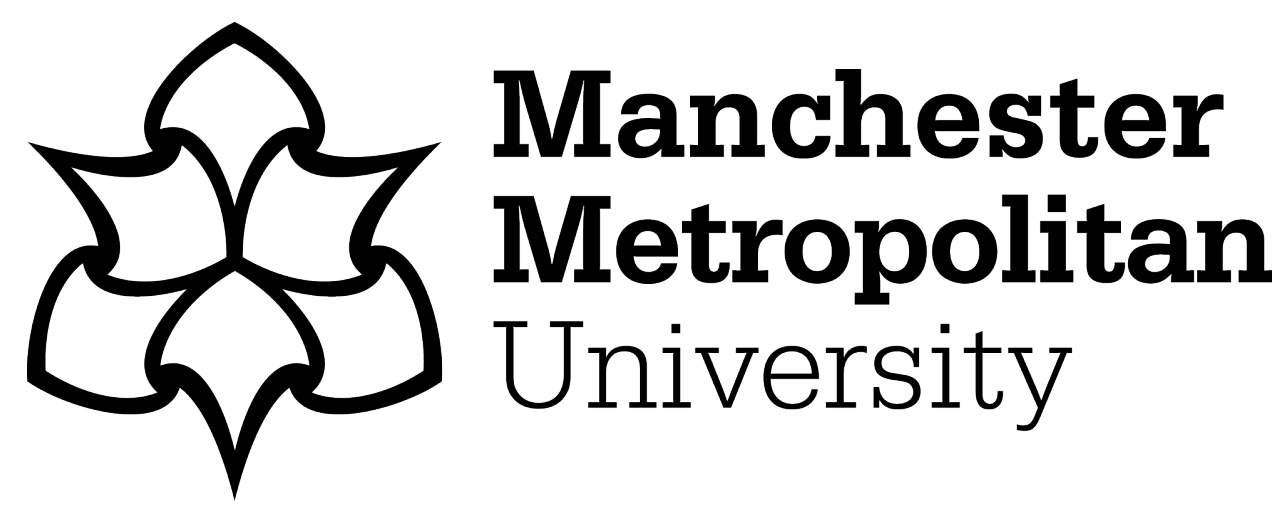

Martins, VWB, Anholon, R, Sanchez-Rodrigues, V, Leal Filho, W and Quelhas, OLG (2021) Brazilian logistics practitioners' perceptions on sustainability: an exploratory study. International Journal of Logistics Management, 32 (1). pp. 190-213. ISSN 0957-4093

Downloaded from: https://e-space.mmu.ac.uk/626420/

Version: Accepted Version

Publisher: Emerald

DOI: https://doi.org/10.1108/IJLM-02-2020-0091

Please cite the published version 


\title{
Brazilian Logistics Practitioners' Perceptions on Sustainability: An Exploratory Study
}

\author{
Martins VWB, Anholon R, Sanchez-Rodrigues V, Leal Filho W, Quelhas OLG \\ International Journal of Logistics Management \\ DOI https://www.emerald.com/insight/content/doi/10.1108/IJLM-02-2020-0091/full/html
}

Purpose: Confronting globalization, logistics systems need to achieve greater efficiency in processes to be competitive. Competitiveness is not related only to economic aspects; companies need to perform their activities aligned to the Triple Bottom Line concept. In this context, the main objective of this research is to analyze how Brazilian professionals think about sustainable logistics through an exploratory study.

Design/methodology/approach: A set of 33 indicators, compiled from a literature review, was used to develop a research instrument applied in a survey of 50 professionals working with logistics processes in Brazilian companies. First, the Cronbach's Alpha non-response bias test was run to verify the questionnaire reliability. Respondents were grouped through Cluster Hierarchical Analysis and their answers were analyzed through TOPSIS technique.

Findings: The results from the sample analysis showed that Brazilian professionals think in the three dimensions of TBL when considering sustainable logistics systems; however, social aspects are relegated to a second level of importance when compared with environmental and economic indicators. In addition, it is possible to highlight that most important environmental aspects are directly related to economic objectives.

Originality/value: There are few studies examining sustainable logistics system in Brazilian companies that consider the purpose mentioned by evidencing originality in the same way as this current study. The results presented here can contribute to amplifying debates in the theme.

Keywords: Sustainable logistics; Sustainability; Sustainable Performance Indicators; Brazilian logistics practitioners

\section{Introduction}

Globalization has directly impacted logistics systems in pursuit of efficiency in processes. To be competitive, companies need to integrate sustainable concepts in logistics activities, since environmental regulations and consumer pressure are increasing for more sustainable services and products (Chu et al., 2019). In the academic literature, it is possible to find studies regarding sustainable logistics systems, showing the interest of academia and market professionals within the mentioned theme (Bebbington and Thomson, 2013; Chandra and Kumar, 2019; Jozef et al., 2019; Lee and Kim, 2011; Lee and Wu, 2014; Velasco et al., 2018).

The logistics system is a set of activities considered strategic for the success of organizations. The activities are divided into key activities and support activities. Management of service levels offered to customers, transportation, inventory management, information flow 
and order processing are considered key activities. Storage, material handling, purchasing management, packaging design and information maintenance are considered support activities (Ballou, 2004; Dang and Yeo, 2018; Martins et al., 2019). The efficient management of logistics activities is essential to companies reaching competitiveness. It is necessary to improve processes continuously, think in a systematic way and provide better services to customers. (Ballou, 2004; El-Berishy et al., 2013; Irfani et al., 2019a; Kuo et al., 2019; Martins et al., 2019). Additionally, Chen and Bibanda (2019) and Eroglu, Kurt and Elwakil (2016) argue that to be competitive, companies need to consider sustainability in logistical activities.

The concept of sustainability most used in the academic and business environment is proposed by UN World Commission on Environment and Development (Brundtland, 1987). According to this concept, sustainability is "meeting the needs of the present without compromising the meeting of future demands" (Brundtland, 1987, p. 16). More specifically, Liu (2018), Yun (2019) and Sirilertsuwan, Ekwall and Hjelmgren (2018) show the concept of sustainability using Triple Bottom Line (TBL) definition. According to this concept (TBL), companies should consider environmental, economic and social aspects in their activities. Logistic systems should create value to companies and positive results to all stakeholders, such as job creation, poverty reduction, and community development (Abbasi and Nilsson, 2016).

The concept of sustainable logistics consists in organizational ability to supply products and services aligned to sustainability guidelines, balancing environmental, social and economic aspects (Chhabra et al., 2018). Aldakhil et al. (2018), Calabrese et al. (2018) and Tseng et. al (Tseng et al., 2018) agree with this point of view and argue that sustainable logistics contribute to the global agenda towards a better future. The management of logistics systems is a complex activity (Nilsson, 2019) because it involves consideration of a large number of variables, parameters and restrictions. The main challenge for managers in adopting sustainable practices in logistics processes is to define the correct balance among the three dimensions of TBL (Lee and Wu, 2014; Schaltegger and Burritt, 2014; Zaman and Shamsuddin, 2017).

The importance of sustainable logistics to companies' future is evident, as mentioned above; however, Frayret et al. (2017) highlight many companies do not correctly consider all TBL guidelines in their operations. The same authors argue that, although there are several propositions in the literature, none of them preset key performance indicators in a simple way to assess sustainable logistics systems correctly (Frayret et al., 2017). Lee and Farzipoor Saen (2012), Lee and $\mathrm{Wu}$ (2014) and Schaltegger and Burritt (2014) agree with the statement, emphasizing that is necessary to integrate traditional performance indicators with sustainability guidelines.

In this sense, it is worth highlighting the efforts present in recent literature, in which it is possible to perceive a growing number of studies analyzing sustainability aspects in logistics systems (Hong et al., 2018). However, it is possible to note that most of studies in this context do not carry out a comparative analysis among environmental, economic and social aspects. Thus, more debates are required about the importance of considering environmental and social aspects with economic issues (Lee and Wu, 2014; Martins et al., 2019; Seuring and Müller, 2008). Stindt (2017) argue that there is lack of guidelines to support comprehensive analysis, 
especially regarding assessment of environmental and social performance, which hinders advances in corporate sustainability. The authors also argue that questions arise about how to measure and balance the respective indicators with traditional economic objectives. The increase in the number of researches in this context can be seen in studies of Agrawal and Singh, 2019; Davis-Sramek et al., 2020; Hojnik et al., 2020; Le et al., 2013; Liu et al., 2018; Torabizadeh et al., 2020; Watanabe et al., 2018.

Focusing on the Brazilian context, it is possible to note that there are several studies related to sustainable logistics systems; however, few of them analyze environmental and social aspects in detail. Regarding the application of sustainable practices in logistics activities, few companies perform these. The explanation for this situation can lie with business focus, lack of strict legislation and low customer pressure (ALVES and NASCIMENTO, 2014; Hisano Barbosa and Andreotti Musetti, 2010; Martins et al., 2019; Penteado Pinto Martins et al., 2012).

In this scenario, the hypothesis is raised that Brazilian professionals of logistics system give less attention to social aspects when considering sustainable activities. In addition, environmental aspects are directly related to economic goals when considered. This hypothesis is corroborated by studies in other regions (Chhabra et al., 2018; Khan et al., 2019; Lee and Wu, 2014; Narayana et al., 2019; Nikolaou et al., 2013). In order to verify the hypothesis mentioned, the research presented in this article aims to identify the comparative importance attached to Brazilian professionals when considering 33 performance indicators to assess sustainable logistic systems.

Further to the introduction section, this paper presents four subsequent sections. Section 2 is dedicated to the theoretical background, highlighting the importance of sustainable logistics systems and the state of the art about the theme. Section 3 shows the methodological procedures used, allowing other researchers to replicate the study. Section 4 presents the findings and debates considering academic literature. Finally, section 5 presents the conclusions and final considerations, as well as future research proposals. The references used are listed at the end of the paper.

\section{Theoretical background}

The logistics sector plays a significant role in global business environment and, in this context, it can make an important contribution to sustainable development goals. The sector mentioned, besides the economic contribution, can provide benefits to society regarding environmental and social aspects (Aldakhil et al., 2018). Abbasi and Nilsson (2016) argue that sustainable logistics systems can generate value for companies at the same time as not harming the environment and contribute to people's better quality of life. Faced with this context, the theme has been attracting attention as an interesting topic for researchers, companies and society (Agrawal and Singh, 2019).

Despite the aforementioned importance, the current logistics sector is still responsible for the consumption of a considerable amount of energy resources and influences greenhouse gases emission (Dahlmann and Röhrich, 2019; Rashidi and Cullinane, 2019). Aldakhil et al. (2018) 
argue with the point of view and highlight the consumption of fossil fuels, non-renewable natural resources and air pollution.

Promoting a sustainable logistics system in companies is not an easy task, because there are many variables to be considered simultaneously in a context of costs, organizational cultural issues, uncertainties, restrictions and different stakeholders' goals (Chakraborty et al., 2020; Jamali and Rasti-Barzoki, 2019; Lan and Zhong, 2018). Furthermore, when present in companies, sustainable practices are more related to economic and environmental issues, leaving social aspects in the background (Chhabra et al., 2018; Khan et al., 2019; Lee and Wu, 2014; Narayana et al., 2019; Nikolaou et al., 2013).

According to Micale et al. (2019), most of the sustainable practices implemented for companies in logistics systems aims to reduce operational costs. They also highlight that environmental and social aspects of sustainability should be considered when designing and reengineering logistics operations. Kumar and Anbanandam (2020) corroborate this statement and highlight that political aspects should also be considered in the insertion of sustainable practices in logistical system.

Melkonyan et al. (2020) state that sustainability needs to be integrated into logistics strategies of organizations, and in doing so, organizations must consider all aspects of valueadding and agile services delivered to clients, including fast delivery, price and sustainability, among others. Moreover, the authors argue that the demand for environmental friendly products and services is increasing, which drive logistics systems to be redefined to accommodate such a mega trend, including aligning the organization strategy with the operation of the logistics component of supply chains, as Gruchmann et al. (2019) emphasize.

Martins et al. (2019) and Frayret et al. (2017) highlight the lack of evaluation models that consider the three pillars of TBL in logistics systems and can help companies in this way. Confronting this statement, the analysis of sustainable indicators to logistics system is very important and becomes a central issue for organizations (Chandra and Kumar, 2019; Irfani et al., 2019b).

The literature presents different sustainable indicators and, to better understand them, the authors of this paper synthesized the information in a table (Table 1). It is important to observe two considerations about Table 1. First, the following table presents the indicators already segregated in TBL guidelines and shows the nomenclatures that will be used in the next section. Second, five of 33 indicators were classified as "general", because they incorporate more than one dimension of TBL.

Table 1. Indicators listed from the literature (Source: see table).

\begin{tabular}{|c|c|}
\hline Environmental Indicators & Authors \\
\hline En_1 - Fuel consumption monitoring & (Zaman and Shamsuddin, 2017) \\
\hline $\begin{array}{c}\text { En_ } \overline{2} \text { - Analysis of adequacy regarding } \\
\text { environmental policies }\end{array}$ & $\begin{array}{c}\text { (Buldeo Rai et al., 2018; Chen et al., 2018; Govindan et } \\
\text { al., 2016; Seguí et al., 2016) }\end{array}$ \\
\hline $\begin{array}{c}\text { En_3 - Transport environmental impact } \\
\text { assessment }\end{array}$ & (Björklund et al., 2016) \\
\hline
\end{tabular}


En_4 - Control of energy consumption

En_5 - Measurement of total water consumption spent on logistics operations En_6 - Amount of waste correctly destined En_- $\overline{7}$ - Measurement of the amount of use of sustainable materials in logistics operations

En_8 - Monitoring of $\mathrm{CO} 2$ emission by developed logistics operation

En_9 - Elaboration and updating of environmental inventory

En_10 - Measurement of the amount of clean energy use

\section{Economic Indicators}

Ec_1 - Mapping of operational logistics costs

Ec_2 - Measurement of the profitability of the logistics system

Ec_3 - Quality assessment of after-care services

Ec_4 - Average journey time per delivery

Ec_5 - Delivery reliability assessment

Ec_6 - Total deliveries served per day

Ec_7 - Distance traveled by total daily working time

Ec_8 - Evaluation of order fulfillment time

Ec_9 - Evaluation of the corporate image of the logistics system

Ec_10 - Rate of filling capacity of means of transport

Ec_11 - Freight quantity fluctuation analysis

Ec_12 - Mapping of information sharing costs
(Asmone et al., 2019; Björklund et al., 2016; Bloemhof et al., 2015a; Buldeo Rai et al., 2018; Chen et al., 2018; Govindan et al., 2016; Kalenoja et al., 2011; Pilouk and

Koottatep, 2017; Zaman and Shamsuddin, 2017)

(Asmone et al., 2019; Björklund et al., 2016; Chen et al., 2018; Pilouk and Koottatep, 2017)

(Govindan et al., 2016)

(Govindan et al., 2016)

(Björklund et al., 2016; Bloemhof et al., 2015b; Buldeo

Rai et al., 2018; Chen et al., 2018; Govindan et al.,

2016; Kalenoja et al., 2011; Morana and Gonzalez-

Feliu, 2015; Sarraj et al., 2014; Zaman and

Shamsuddin, 2017)

(Chen et al., 2018; Seguí et al., 2016)

(Asmone et al., 2019; Routroy and Pradhan, 2014)

Authors 2008; Pilouk and Koottatep, 2017; Routroy and Pradhan, 2014; Sarraj et al., 2014)

(Irfani et al., 2019b)

(Govindan et al., 2016)

(Sarraj et al., 2014; Schulz and Heigh, 2009)

(Govindan et al., 2016; Kunadhamraks and Hanaoka, 2008)

(Schulz and Heigh, 2009)

(Morana and Gonzalez-Feliu, 2015)

(Chae, 2009)

(Govindan et al., 2016; Irfani et al., 2019b)

(Sarraj et al., 2014)

(Lan and Tseng, 2018)

(Govindan et al., 2016)

\section{Social Indicators \\ So_1 - Measurement of employee satisfaction in the workplace \\ So_2 - Monitoring the impacts of operations on neighboring communities \\ So_3 - Evaluation of occupational health and safety in the corporate environment \\ So_4 - Social demands employability index \\ So_5 - Participatory management index \\ So_6 - Satisfaction rate of inhabitants of neighboring communities}

Ge_1 - Assessment of long-term strategic objectives

Ge 2 - Assessment of the level of understanding of employees regarding sustainability

Ge_3 - Number of suppliers that meet sustainability aspects

\section{Authors}

(Irfani et al., 2019b; Pilouk and Koottatep, 2017)

(Govindan et al., 2016; Pilouk and Koottatep, 2017; Seguí et al., 2016)

(Govindan et al., 2016)

(Govindan et al., 2016)

(Pilouk and Koottatep, 2017)

(Morana and Gonzalez-Feliu, 2015)

\section{Authors}

(Routroy and Pradhan, 2014)

(Seguí et al., 2016)

(Björklund et al., 2016; Routroy and Pradhan, 2014) 
Ge_4 - Frequency of publishing
sustainability reports

Ge_5 - Analysis of the customer's perception of the logistics process
(Seguí et al., 2016)

(Govindan et al., 2016)

It is worth highlighting some recent studies of literature review and bibliometric analysis carried out in the same context but with different objectives. Zhao at al. (2020) conducted a literature review to identify the most important topics, explore gaps in knowledge and recommend future directions in the context of sustainable logistics, specifically regarding sustainable transport. Their findings showed nine research topics, with emphasis on indicators of sustainable transport and performance models, corroborating the importance of indicators analysis developed here. Lan and Tseng (2018) developed a study to develop a set of indicators through the literature review for logistics in metropolitan regions to improve economic development of operations. This context is also related to the study developed here.

Another important review in this context was developed by Ahmad et al., (2019). The authors aimed to review indicators for the three aspects of TBL to be used in manufacturing operations. The authors found that the economic evaluation was mainly limited to cost-based indicators and that, from a social point of view, it considered aspects of the community as priority, leaving customers' needs in the background. Abedini et al. (2020) also analyzed indicators considering the TBL concepts and identified that there is no holistic model considering the three pillars of TBL in the development of production operations, therefore, comparatively analyzing the perception of logistics practitioners regarding the three pillars of TBL, it becomes important to deepen the debates in this context.

Hojnik et al. (2020) carried out a systematic review of the literature on sustainability indicators and validated through expert analysis, validated applying it in 18 different companies. Finally, the authors categorized the set of indicators proposed through TBL guidelines. Thus, it is possible to note the use of environmental, economic, and social aspects of TBL in different contexts, in this case in the yachting industry. In addition to the study related to performance indicators for sustainable logistical systems, the authors of this article also analyzed the "state of the art" to the theme. Relevant studies were analyzed and a synthesis of them is presented below.

Morana and Gonzalez-Feliu (2015) present in their study a proposal of indicators to assess sustainable performance of the urban delivery systems. During the research, indicators were chosen by managers individually and, subsequently, in small groups. It was possible to note different points of view, highlighting that professionals do not have a consensus about the theme. Still in the context of urban logistics, Rai et al. (2018) developed a research to define indicators to assess sustainable logistics of cities. The authors proposed a comprehensive set of indicators related to freight transport aligned with urban policies. Using these indicators, local, authorities can assess and improve urban logistical sustainability. Regarding this theme, the authors note a lack of understanding regarding the topic, despite the negative impact provided on air pollution. 
In the context of port logistics, Chen and Pak (2017) conducted a study to define a set of indicators to assess sustainable operations in three Chinese ports. The results present 21 indicators divided into six dimensions: liquid pollution management, air pollution management, noise control, low carbon regulations and energy savings, preservation of marine biology and management indicators. Still in the context of port logistics, Carlucci et al. (2018) conducted an analysis to define factors that affect the logistical and economic performance of 20 ports in Europe. The results of the mentioned study show that it is possible to increase economic value respecting standards of environmental quality.

Focusing logistical operations on vaccine distribution, Chandra and Kumar (2019) conducted a study to identify performance indicators to better control the Universal Immunization Program in India. The results provide contributions to management of the program, improve the performance of vaccine delivery and childhood immunization.

Helo and Ala-Harja (2018) analyzed the logistical activities of the food industry considering environmental aspects with the main traditional performance indicators. The analysis focused on aspects of order picking, transportation, storage and distribution. Through the indicators, it was possible to perceive the energy saving potential of logistical processes mentioned.

Khan et al. (2017) examined the relationship between environmental logistics performance indicators and specific growth factors in 15 different countries from 2007 to 2015. The results indicate that sustainable logistic systems improved the conscious consumption of energy, economic and sectoral growth of countries. Additionally, Khan and Qianli (2017) examined the association between economic and environmental indicators with the performance of sustainable logistics. It was possible to note foreign investments were attracted by environmental policies and practices in logistics operations, generating new opportunities.

In another study, Khan et al. (2019) analyzed sustainable logistics operations of countries belonging to South Asian Association for Regional Cooperation. The results showed that the consumption of fossil fuels is the center of logistics operations and negative effects are generated on society and environment. There are many opportunities to improve environmental sustainability in terms of carbon emissions. The authors also point out the need for more studies that propose performance indicators for sustainable logistics systems.

Björklund and Forslund (2018) argue that more innovative organizational thinking is required to achieve the sustainability targets that logistics operations have currently. The authors also propose a set of logistic innovation indicators to identify the correlation between those indicators and the success of sustainable practices in the development and running of logistics systems. Golroudbary et al (2019) emphasize that in order to better plan and undertaken the implementation of sustainability innovation, the negative environmental effects of logistics operations should be thoroughly evaluated. The authors claim that it is necessary to recognize, develop and promote sustainable practices and policies to ensure a fair balance among the economic and social elements of performance. 
Analyzing the information mentioned above regarding sustainable logistics and performance indicators, it is possible to verify the relevance of the theme and their range. Many authors are developing studies in order to improve performance of sustainable logistics systems and enlarge debates about the indicators more adequate.

\section{Methodological procedures}

To develop this research, the following steps were performed: a) literature review on sustainable logistics and performance indicators used in the context of sustainability; b) definition of the indicators used to construct the research instrument; c) survey carried out with 50 Brazilian professionals who act with "logistics systems" activities; d) Cronbach's Alpha calculation to identify the reliability of the research instrument; respondents grouping via Cluster Hierarchical Analysis and data analysis using TOPSIS technique; e) establishment of conclusions about the findings.

The literature review was conducted on scientific bases Emerald Insight, Science Direct, Taylor \& Francis, Springer and Wiley, aiming to find papers to establish the theoretical background and to list the set of indicators. The following terms were used in this process: "Sustainable logistics", "Green logistics", "Key indicators in logistics systems" and "Indicators in sustainable logistics". In order to guarantee the robustness of the information and the possibility of replication in other researches, it should be noted that the procedures mentioned above were developed based on the systematic review of literature proposed by Xavier et al., (2017) and Denyer and Tranfield (2009). This approach consists of a protocol composed of the following steps: Formulation of a research question; Study location; Selection and evaluation of studies; Analysis and synthesis, and; Reporting and use of research results. A summary of this protocol is shown in Figure 1.

Figure 1. Literature review protocol.

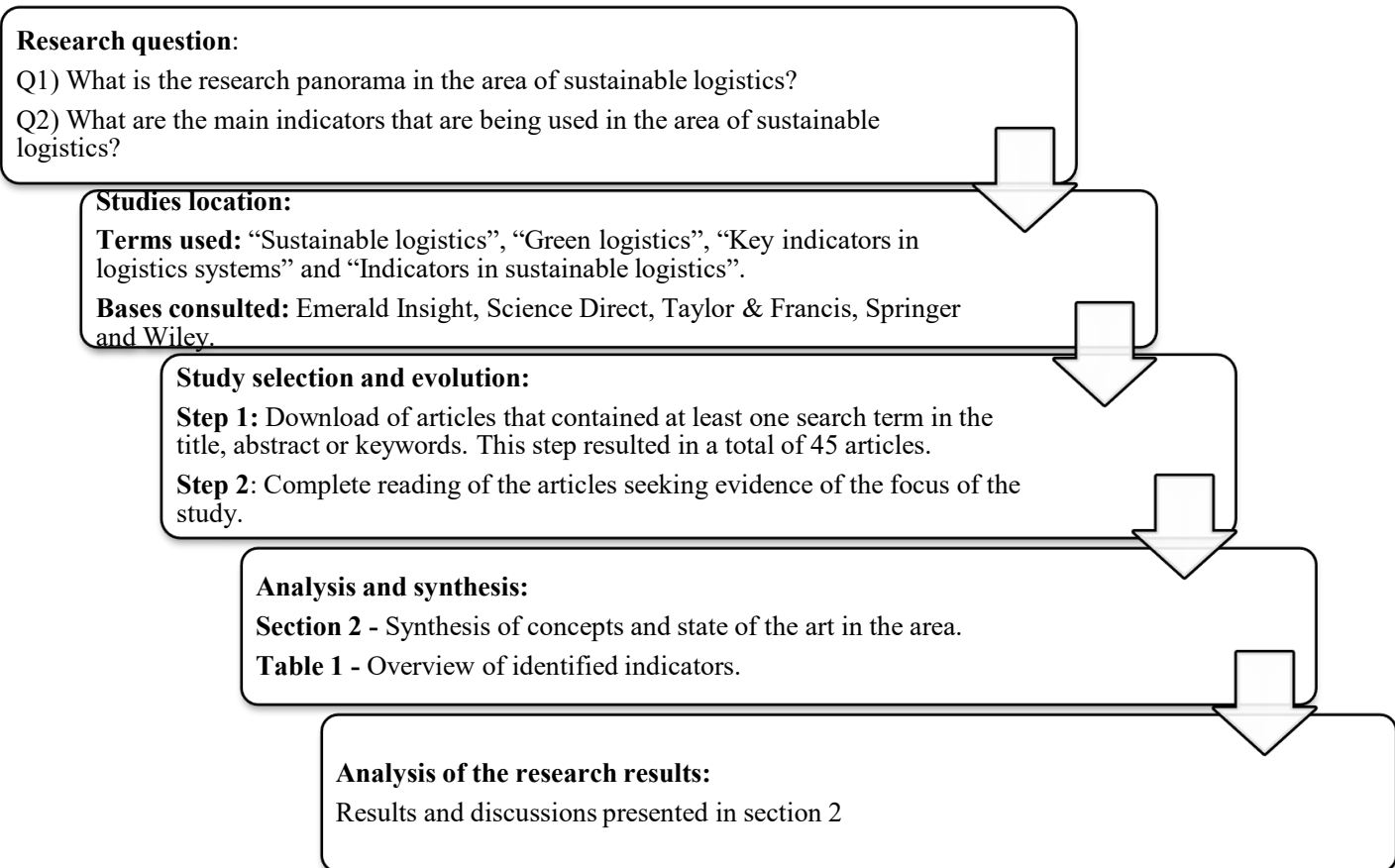


The analysis of the literature allowed the construction of Table 1 and this content was used to structure the research instrument used in the survey. Using classifications presented in the literature, the indicators analyzed were grouped in triple bottom line dimensions. It is important to remember that five of them are classified in a general class because more than one dimension was contemplated.

In the research instrument (questionnaire), for each 33 indicators, the professionals consulted should indicated a note using a scale from 1 to 3 . Note 1 referred to an indicator considered "not important" to assess sustainability in the context; note 2 to an indicator "important but not essential" to assess sustainability in the context; and, finally, note 3 was associated with an indicator considered "essential" to assess sustainability in the context. The authors of this paper opted for a three-point scale because they believe that this choice allows respondents a more pragmatic direction of their perceptions.

The research instrument and other information related to this study were submitted to a Research Ethics Committee and approved. It is important to remember that in Brazil research involving human beings, even as an opinion, needs to be appreciated by an ethics committee. This procedure is established by resolution 466/2012.

After approval, data collection with professionals began. An invitation was sent via email and the questionnaire was available to respondents on the Google Forms platform for a period of two months. The invitation via e-mail was sent to 206 professionals and 50 of them accepted to participate (return rate of 24.27\%). Regarding respondent's characterization, they are professionals who act in logistics Brazilian companies; $22 \%$ of them are were directors, $14 \%$ coordinators, $36 \%$ managers, $10 \%$ supervisors and $18 \%$ analysts of logistics operations. Regarding experience, $32 \%$ have more than 20 years of experience, $28 \%$ have between 10 and 20 years of experience and $40 \%$ have less than 10 years of experience. In this sample, there are professionals from five Brazilian regions: $37 \%$ are from Southeast, 32\% from North, $12 \%$ from Northeast, 11\% from Northeast, 11\% from South and 8\% from Midwest. Therefore, it is possible to state that the sample represents the views of professionals from different regions. It was possible to weigh the opinion of each professional, considering the time of experience in logistics area and sustainability, scholar background and the job position they occupy in current company.

Once the database with the survey was obtained the calculation of Cronbach's Alpha was performed to guarantee the research instrument reliability. This calculation followed the recommendations proposed by Christmann and Van Aelst (2006) and resulted in a coefficient value equal to 0.89 , demonstrating the reliability of the research instrument used. Then, data analysis started through the Hierarchical Cluster Analysis statistics technique aiming to identify how the respondents are grouped in relation to their similarities in terms of experience in logistics area and sustainability, their scholar background and the job position they hold in the company. For each category mentioned, scores 1, 2 or 3 were assigned according to the details presented in Table 2.

Table 2. Scores for each category considered. Source: Authors. 


\begin{tabular}{|c|c|c|}
\hline $1=$ Up to 10 years & $1=$ graduation & $\begin{array}{c}1=\text { coordinators, supervisors and } \\
\text { analysts }\end{array}$ \\
\hline $2=$ From 11 to 20 years & $\begin{array}{c}2=\text { postgraduate }(\mathrm{Mba} \text { or Master } \\
\text { Degree })\end{array}$ & $2=$ managers \\
\hline $3=$ More than 20 years & $3=$ postgraduate $(\mathrm{PhD})$ & $3=$ directors \\
\hline
\end{tabular}

The Hierarchical Cluster Analysis was developed based on the words undertaken by Arbolino et al. (2019) and Malhotra (2012). For the Hierarchical Cluster Analysis, Ward method was used, in which the smallest variance increase between the groups is considered, being possible to verify the variance through the means of the variables of each group. Then, cluster analysis allowed the identification of the best segregation according to the number of groups considered most suitable for this analysis. The results of Hierarchical Cluster Analysis can be presented in a graphical way using the dendrogram, in which it was possible to analyze the groups according to their hierarchy. This calculation was performed using the SPSS 24 software by using the following parameters: classification, hierarchical cluster, dendrogram, clustering method, Ward, Euclidean distance, Z score standardization, cluster analysis by cases and cut-off point for defining the groups the combined distance equal to 10 . Five groups were generated and their details are presented in the results section.

The data gathered from the survey were stratified into five groups according to Hierarchical Cluster Analysis development. After that, to continue the analysis, the guidelines proposed by Singh et al. (2016) for the development of the TOPSIS technique were followed. According to the mentioned authors, TOPSIS allows the ranking of alternatives considering different analysis criteria. This method was used to allow the classification of alternatives considering different criteria (which can be weighted differently), this is precisely the case presented here, since the authors of this article understand that professionals with greater experience in logistics activities, scholar background and the job position they occupy in the company interfere in their expertise and experience to evaluate the indicators considered in this study.

It is worth highlighting that the literature presents relevant studies that previously used TOPSIS method in the logistical context can be highlighted: Moon et al. (2015) analyzed the competitiveness of six transport routes between Korea and Europe evaluating criteria such as total transport distance, total transport time, total transport cost, service level and transport security; Pereira et al. (2020) analyzed lean warehousing practices performed in Brazilian companies context, in order to assess the most and the less adopted, in an exploratory character.

In this research, different weights were assigned to each of the 5 groups generated by the Hierarchical Cluster Analysis as it can be seen in the results section. These weights were assigned based on the characteristics of each group considering the time of experience in the area, scholar background and the position in the company. Comparative ordering via TOPSIS can be achieved through seven steps (see Figure 2). In the first, a matrix D with elements $\left(\mathrm{x}_{\mathrm{ij}}\right)$ must be structured, where (i) refer to alternatives and (j) refer to analysis criteria. In the case of this study, the alternatives corresponded to the 33 indicators presented in Table 1 and the criteria corresponded to the averages attributed by each group of respondents. The mathematical 
representation of matrix D is shown in Equation 1. The second step refers to the normalization of matrix D through Equation 2, resulting in a matrix called Matrix R according to Equation 3. Equations 1, 2 and 3 can be seen in Figure 2.

The third step is the weighting of the values of Matrix $\mathrm{R}$ using Equation 4, obtaining Matrix V. Then, the ideal positive $\left(\mathrm{v}_{j}{ }^{+}\right)$and negative $\left(\mathrm{v}_{\mathrm{j}}{ }^{-}\right)$ideal solutions that characterize the fourth step are determined. Ideal positive $\left(\mathrm{v}_{j}{ }^{+}\right)$and negative $\left(\mathrm{v}_{\mathrm{j}}^{-}\right)$solutions are the maximum and minimum values respectively existing in Matrix $\mathrm{V}$ for each of the analysis criteria. This procedure was necessary to perform the fifth step, in which the positive and negative Euclidean distances of each alternative were calculated. For this, Equations 6 and 7 presented in Figure 2 were used. Finally, having the values of Euclidean distances, it was possible to calculate the $\mathrm{C}_{\mathrm{i}}{ }^{*}$ indicator and, through it, rank the 33 indicators that were analyzed by professionals via survey. It should be noted that the $\mathrm{Ci}^{*}$ values must be between 0 and 1 . The $\mathrm{Ci}^{*}$ indicator was calculated using Equation 8 also shown in Figure 2.

Figure 2. Equations used in the TOPSIS technique.

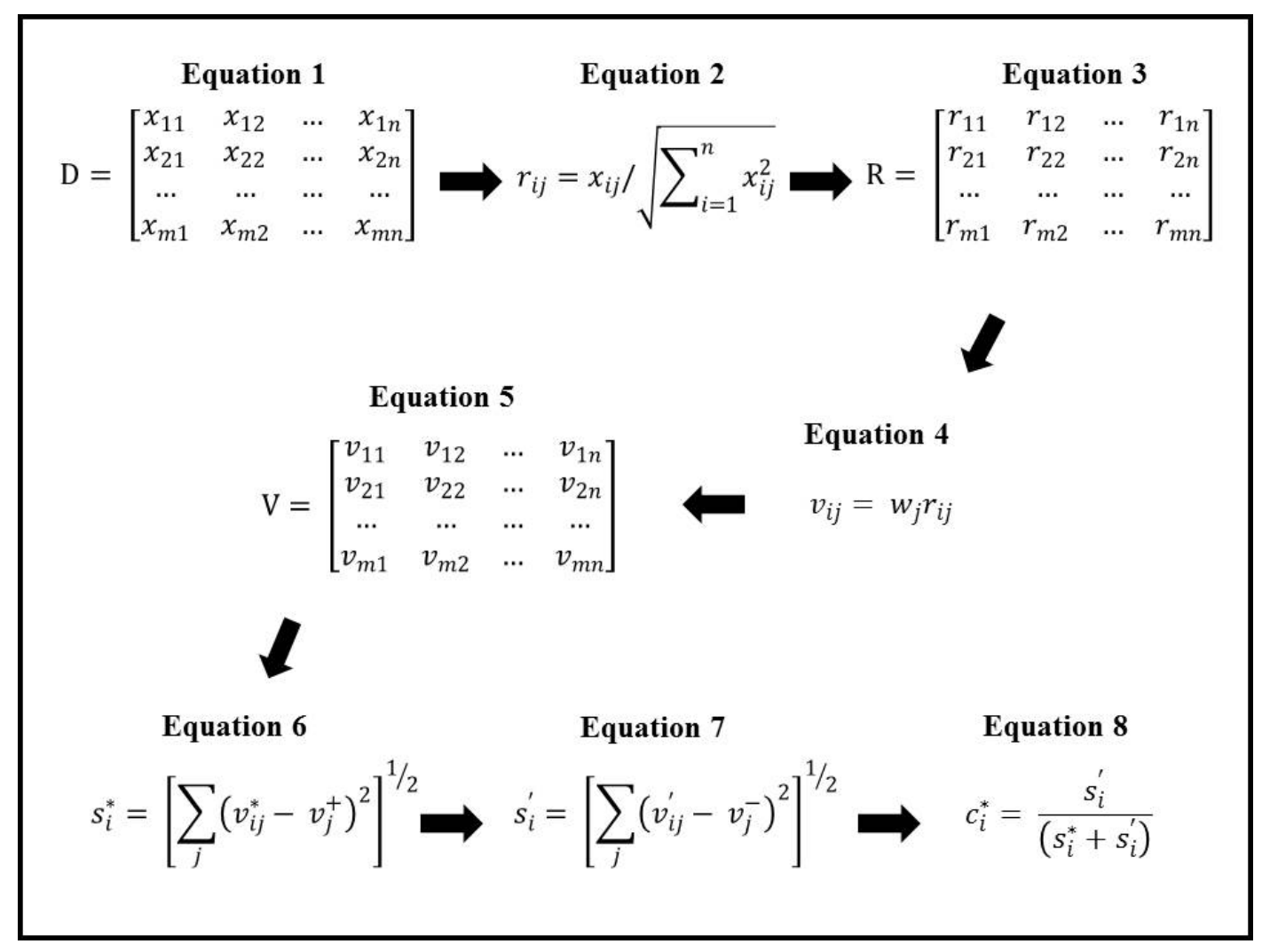

Source: (Singh et al., 2016).

\section{Results and associated discussions}

This section presents the results and discussions according to the data analysis performed.

\subsection{Hierarchical Cluster Analysis}


According to respondents' data, it was possible to structure Table 3 considering the time of experience in the area of logistics and sustainability, scholar background and the job position that they occupy in the company, assigning the scores presented in Table 2.

Table 3. Scores attributed to respondents. Source: Authors.

\begin{tabular}{|c|c|c|c|c|c|c|c|}
\hline Respondents & $\begin{array}{c}\text { Time of } \\
\text { experience }\end{array}$ & $\begin{array}{c}\text { Scholar } \\
\text { background }\end{array}$ & $\begin{array}{l}\text { Position } \\
\text { in } \\
\text { company }\end{array}$ & Respondents & $\begin{array}{c}\text { Time of } \\
\text { experience }\end{array}$ & $\begin{array}{c}\text { Scholar } \\
\text { background }\end{array}$ & $\begin{array}{c}\text { Position } \\
\text { in } \\
\text { company }\end{array}$ \\
\hline R1 & 3 & 3 & 1 & $\mathrm{R} 26$ & 3 & 2 & 3 \\
\hline $\mathrm{R} 2$ & 3 & 1 & 3 & $\mathrm{R} 27$ & 3 & 2 & 3 \\
\hline R3 & 2 & 2 & 3 & $\mathrm{R} 28$ & 3 & 2 & 2 \\
\hline $\mathrm{R} 4$ & 2 & 2 & 2 & R29 & 3 & 1 & 2 \\
\hline R5 & 2 & 2 & 1 & R30 & 3 & 1 & 2 \\
\hline R6 & 1 & 2 & 1 & R31 & 2 & 2 & 2 \\
\hline R7 & 1 & 2 & 3 & R32 & 2 & 2 & 1 \\
\hline $\mathrm{R} 8$ & 1 & 2 & 2 & R33 & 2 & 1 & 1 \\
\hline R9 & 1 & 1 & 1 & R34 & 2 & 1 & 1 \\
\hline R10 & 1 & 1 & 1 & R35 & 2 & 2 & 2 \\
\hline R11 & 1 & 2 & 3 & R36 & 2 & 1 & 1 \\
\hline R12 & 1 & 1 & 1 & R37 & 2 & 2 & 1 \\
\hline R13 & 1 & 1 & 1 & R38 & 2 & 2 & 2 \\
\hline R14 & 1 & 2 & 2 & R39 & 2 & 2 & 2 \\
\hline $\mathrm{R} 15$ & 1 & 2 & 3 & $\mathrm{R} 40$ & 2 & 2 & 1 \\
\hline R16 & 1 & 1 & 3 & R41 & 2 & 1 & 2 \\
\hline R17 & 3 & 2 & 3 & R42 & 1 & 1 & 2 \\
\hline R18 & 3 & 2 & 2 & R43 & 1 & 1 & 1 \\
\hline R19 & 3 & 2 & 1 & R44 & 1 & 1 & 1 \\
\hline R20 & 3 & 2 & 2 & R45 & 1 & 1 & 1 \\
\hline R21 & 3 & 2 & 3 & R46 & 1 & 1 & 1 \\
\hline R22 & 3 & 1 & 3 & R47 & 1 & 1 & 2 \\
\hline R23 & 3 & 2 & 1 & R48 & 1 & 1 & 2 \\
\hline R24 & 3 & 2 & 2 & R49 & 2 & 2 & 2 \\
\hline R25 & 3 & 3 & 3 & R50 & 1 & 2 & 1 \\
\hline
\end{tabular}

Figure 3 shows the dendrogram obtained through Hierarchical Cluster Analysis and the groups identified.

Figure 3. Dendogram of similarity. Source: Authors based on research data. 


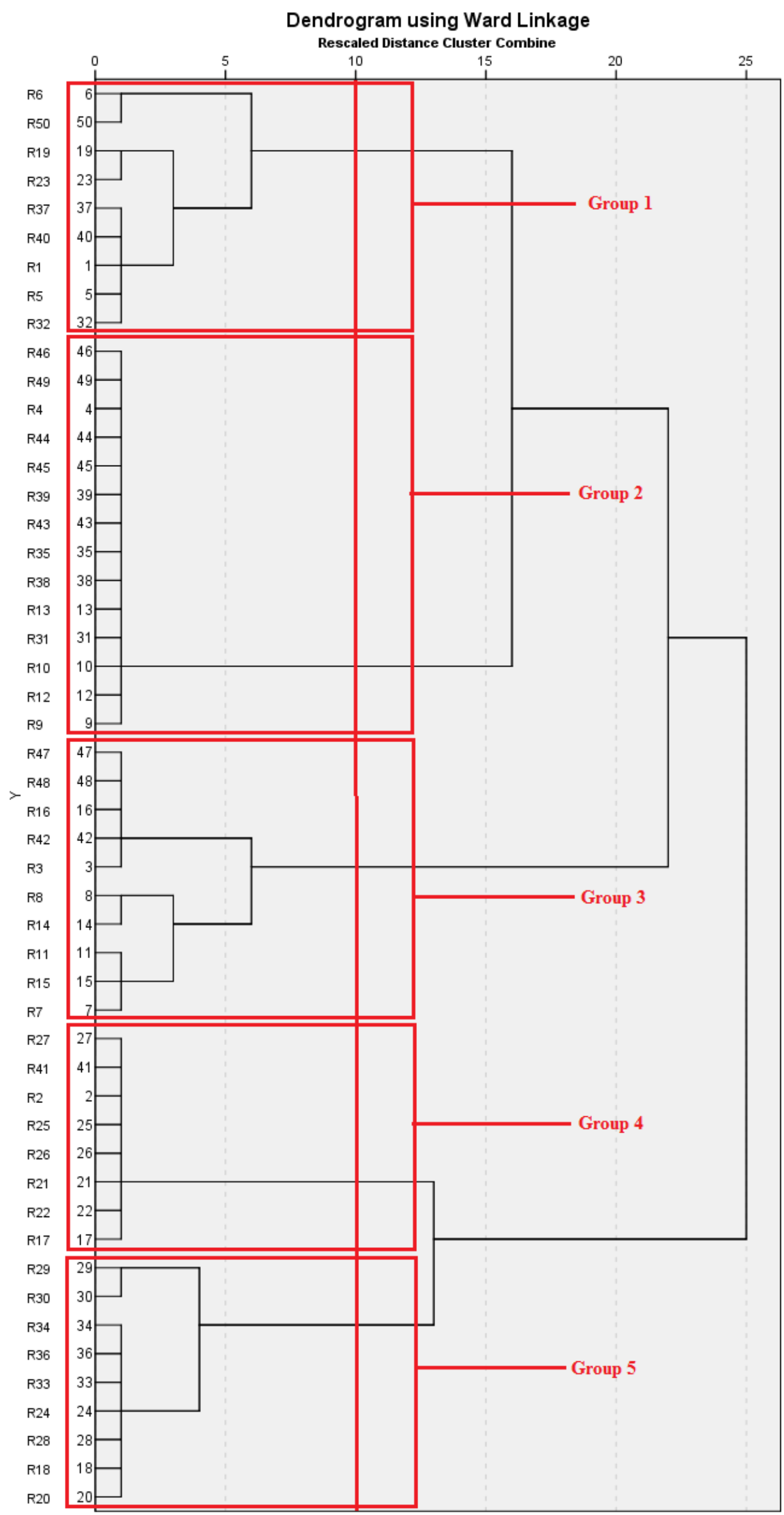


In Figure 3, it is possible to observe a cut line that establishes the rescaled distance used in the analysis (defined as 10). From Dendrogram analysis, 5 groups were identified, which were weighted according to the identified characteristics of each considering the time of experience in the area, scholar background and the job position in the company. The weightings are related to the probability of respondents better to assess the context.

Group 4 received the highest weight, since $90 \%$ of its respondents have more than 20 years of experience in the area, $90 \%$ hold positions of directors in their companies and $62 \%$ have expertise in the area at the level and MBA. The weight attributed for this group was 0.35 . The second group with the highest weight was Group 5, in which $66 \%$ of the respondents have more than 20 years of experience in the area, 66\% occupy managerial positions in their companies and $44 \%$ have specialization in the area (MBA or Master degree). A weight of 0.25 was assigned for this group. The group with intermediate weight was Group 3, in which $90 \%$ have up to 10 years of experience in the area, $50 \%$ occupy positions of directors and $60 \%$ have specialization in the area at the level of MBA or Master's. A weight of 0.20 was assigned for this group. Both Group 1 and Group 2 received a weight of 0.10 . These groups are characterized by their respondents having little experience in the area, the vast majority occupying initial positions in companies such as analysts, coordinators, and supervisors and with a considerable number of professionals who have only college degree.

With the identification of groups and weights to the indicators were ranked through TOPSIS Technique. The results are presented in the following section.

\subsection{Technique for Order of Preference by Similarity to Ideal Solution (TOPSIS)}

Firstly, the averages assigned by each group of professionals for 33 indicators were calculated, as showing in Table 4.

Table 4. Average grade for each group for each item. Source: Authors.

\begin{tabular}{cccccc}
\hline Items & Group 1 & Group 2 & Group 3 & Group 4 & Group 5 \\
\hline En_1 & 2.89 & 2.79 & 2.70 & 2.88 & 2.67 \\
En_2 & 2.78 & 2.50 & 2.70 & 2.88 & 2.89 \\
En_3 & 2.67 & 2.36 & 2.40 & 2.75 & 2.56 \\
En_4 & 2.67 & 2.36 & 2.50 & 2.88 & 2.67 \\
En_5 & 2.56 & 2.14 & 2.70 & 2.63 & 2.67 \\
En_6 & 2.44 & 2.43 & 2.70 & 2.63 & 2.56 \\
En_7 & 2.44 & 2.29 & 2.40 & 2.75 & 2.44 \\
En_8 & 2.56 & 2.07 & 2.50 & 2.75 & 2.56 \\
En_9 & 2.67 & 2.36 & 2.60 & 2.63 & 2.67 \\
En_10 & 2.33 & 2.14 & 2.40 & 2.75 & 2.67 \\
Ec_1 & 3.00 & 2.93 & 2.60 & 2.75 & 2.67 \\
Ec_2 & 3.00 & 3.00 & 2.50 & 2.38 & 2.56 \\
Ec_3 & 3.00 & 2.57 & 2.60 & 2.38 & 2.56 \\
Ec_4 & 2.78 & 2.50 & 2.60 & 2.13 & 2.56 \\
Ec_5 & 3.00 & 2.86 & 2.50 & 2.00 & 2.67 \\
Ec_6 & 2.67 & 2.71 & 2.70 & 2.13 & 2.56 \\
Ec_7 & 2.00 & 2.50 & 2.30 & 2.38 & 2.22 \\
Ec_8 & 2.89 & 2.86 & 2.40 & 2.00 & 2.33 \\
Ec_9 & 2.67 & 2.43 & 2.30 & 1.63 & 2.22 \\
Ec_10 & 2.33 & 2.93 & 2.50 & 2.00 & 2.56 \\
\hline
\end{tabular}




\begin{tabular}{llllll}
\hline Ec_11 & 2.22 & 2.57 & 2.30 & 1.63 & 1.89 \\
\hline Ec_12 & 2.44 & 2.00 & 2.10 & 1.38 & 2.00 \\
So_1 & 2.89 & 2.93 & 2.30 & 2.38 & 2.56 \\
So_2 & 2.44 & 2.29 & 2.60 & 1.88 & 2.22 \\
So_3 & 2.89 & 3.00 & 2.40 & 2.25 & 2.67 \\
\hline So_4 & 2.33 & 2.21 & 2.20 & 1.75 & 2.22 \\
So_5 & 2.56 & 2.43 & 2.50 & 2.00 & 2.11 \\
So_6 & 2.33 & 1.93 & 2.00 & 1.63 & 1.78 \\
Ge_1 & 3.00 & 3.00 & 2.50 & 1.75 & 2.22 \\
Ge_2 & 2.56 & 2.43 & 2.70 & 2.50 & 2.44 \\
Ge_3 & 2.22 & 2.50 & 2.30 & 2.88 & 2.56 \\
Ge_4 & 2.44 & 2.29 & 2.70 & 2.25 & 2.11 \\
Ge_5 & 2.78 & 2.50 & 2.30 & 2.13 & 2.44 \\
\hline
\end{tabular}

When analyzing the averages obtained in Group 4 based on the scale adopted, it is possible to observe that the indicators that received the highest averages are: "Monitoring of fuel consumption", "Analysis of adaptations regarding environmental policies", "Control of energy consumption" and "Number of suppliers that meet sustainability aspects". All these indicators presented an average of 2.88; 3 of them are related to environmental management aspects and 1 is classified as general but it has a strong impact on triple bottom line environmental issues. In contrast, the indicator that received the lowest average was: "Mapping of information sharing costs", presenting an average of 1.38, pertaining to the economic aspect of the triple bottom line. Analyzing in general the averages of the 33 indicators, it is clear that the perception of this group of professionals about sustainable aspects in logistics systems is characterized by the prioritization of environmental and economic aspects, leaving important social aspects in the background. In this sense, Zaman and Shamsuddin (2017) emphasize the importance of balancing sustainable performance through consideration of environmental, economic and social approaches in the context of the management of logistics systems.

Considering the averages obtained through the responses from professionals in Group 5 (second highest weight attributed), the scenario is similar to that of Group 4. The indicator that presented the highest average was "Analysis of adequacy regarding environmental policies" with an average of 2.89 , being, therefore, considered the most relevant for this group of professionals. The indicator that received the lowest average was "Satisfaction rate of inhabitants of neighboring communities", related to the social aspect, with an average of 1.78. When analyzing the averages of the 33 indicators of this group, in general, it is possible to identify a scenario in which environmental and economic aspects stand out. This scenario is still worrying, because according to Aldakhil et al. (2018) sustainable logistics plays a fundamental role in achieving global sustainability, enhancing the organizational result not only of economic and environmental factors, but also of social aspects. This understanding is supported by Calabrese et al. (2018); Tseng et al. (2018).

In the analysis of the averages obtained through responses from professionals in Group 3 (the third highest weight among the groups), it is noticed that seven indicators presented average of 2.70 (the highest average of the group); among them, 4 are related to environmental aspects, 1 is related to economic aspects and 2 are classified as general. In contrast, as in Group 5, an indicator related to the social aspect presented the lowest average. Groups 1 and 2 (lowest weights assigned), in general, also presented similar results to the other groups, prioritizing 
environmental and economic aspects. Therefore, it is possible to perceive the coherence between the groups of respondents where, in general, all groups prioritized the economic and environmental aspects over the social aspects. Frayret et al. (Frayret et al., 2017) highlight the deficiency on the part of researchers and professionals in the context of sustainable logistics, mainly due to the divergent understanding of concepts in this context, generally not taking into account all the sustainable aspects relevant to the management of logistics systems.

TOPSIS technique was used to rank the indicators. Its use enabled the authors to attribute weights for participants groups according to their experience level. It is worth mentioning that the data collected in the research were divided into five different groups (see Figure 3). Based on the averages shown in Table 4, the values were normalized using Equation 2 shown in Figure 2, resulting in Matrix R, shown in Table 5.

Table 5. Matrix R with normalized values. Source: Authors.

\begin{tabular}{cccccc}
\hline Items & Group 1 & Group 2 & Group 3 & Group 4 & Group 5 \\
\hline En_1 & 0.19 & 0.19 & 0.19 & 0.21 & 0.19 \\
En_2 & 0.18 & 0.17 & 0.19 & 0.21 & 0.21 \\
En_3 & 0.18 & 0.16 & 0.17 & 0.21 & 0.18 \\
En_4 & 0.18 & 0.16 & 0.18 & 0.21 & 0.19 \\
En_5 & 0.17 & 0.15 & 0.19 & 0.20 & 0.19 \\
En_6 & 0.16 & 0.17 & 0.19 & 0.20 & 0.18 \\
En_7 & 0.16 & 0.16 & 0.17 & 0.21 & 0.17 \\
\hline En_8 & 0.17 & 0.14 & 0.18 & 0.21 & 0.18 \\
En_9 & 0.18 & 0.16 & 0.18 & 0.20 & 0.19 \\
En_10 & 0.15 & 0.15 & 0.17 & 0.21 & 0.19 \\
Ec_1 & 0.20 & 0.20 & 0.18 & 0.21 & 0.19 \\
Ec_2 & 0.20 & 0.21 & 0.18 & 0.18 & 0.18 \\
Ec_3 & 0.20 & 0.18 & 0.18 & 0.18 & 0.18 \\
Ec_4 & 0.18 & 0.17 & 0.18 & 0.16 & 0.18 \\
\hline Ec_5 & 0.20 & 0.20 & 0.18 & 0.15 & 0.19 \\
Ec_6 & 0.18 & 0.19 & 0.19 & 0.16 & 0.18 \\
Ec_7 & 0.13 & 0.17 & 0.16 & 0.18 & 0.16 \\
Ec_8 & 0.19 & 0.20 & 0.17 & 0.15 & 0.17 \\
Ec_9 & 0.18 & 0.17 & 0.16 & 0.12 & 0.16 \\
\hline Ec_10 & 0.15 & 0.20 & 0.18 & 0.15 & 0.18 \\
Ec_11 & 0.15 & 0.18 & 0.16 & 0.12 & 0.13 \\
Ec_12 & 0.16 & 0.14 & 0.15 & 0.10 & 0.14 \\
So_1 & 0.19 & 0.20 & 0.16 & 0.18 & 0.18 \\
So_2 & 0.16 & 0.16 & 0.18 & 0.14 & 0.16 \\
So_3 & 0.19 & 0.21 & 0.17 & 0.17 & 0.19 \\
So_4 & 0.15 & 0.15 & 0.15 & 0.13 & 0.16 \\
So_5 & 0.17 & 0.17 & 0.18 & 0.15 & 0.15 \\
So_6 & 0.15 & 0.13 & 0.14 & 0.12 & 0.13 \\
Ge_1 & 0.20 & 0.21 & 0.18 & 0.13 & 0.16 \\
Ge_2 & 0.17 & 0.17 & 0.19 & 0.19 & 0.17 \\
Ge_3 & 0.15 & 0.17 & 0.16 & 0.21 & 0.18 \\
Ge_4 & 0.16 & 0.16 & 0.19 & 0.17 & 0.15 \\
Ge_5 & 0.18 & 0.17 & 0.16 & 0.16 & 0.17 \\
\hline & & & & & \\
\hline
\end{tabular}

Then, the weights of each group of respondents were considered, according to the values presented in section 4.1. By using this procedure, it was possible to obtain Matrix V, as shown in Table 6. 


\begin{tabular}{cccccc}
\hline Items & rijG1*0.10 & rijG2*0.10 & rijG3*0.20 & rijG4*0.35 & rijG5*0.25 \\
\hline En_1 & 0.02 & 0.02 & 0.04 & 0.08 & 0.05 \\
\hline En_2 & 0.02 & 0.02 & 0.04 & 0.08 & 0.05 \\
\hline En_3 & 0.02 & 0.02 & 0.03 & 0.07 & 0.05 \\
\hline En_4 & 0.02 & 0.02 & 0.04 & 0.08 & 0.05 \\
\hline En_5 & 0.02 & 0.01 & 0.04 & 0.07 & 0.05 \\
\hline En_6 & 0.02 & 0.02 & 0.04 & 0.07 & 0.05 \\
\hline En_7 & 0.02 & 0.02 & 0.03 & 0.07 & 0.04 \\
\hline En_8 & 0.02 & 0.01 & 0.04 & 0.07 & 0.05 \\
\hline En_9 & 0.02 & 0.02 & 0.04 & 0.07 & 0.05 \\
\hline En_10 & 0.02 & 0.01 & 0.03 & 0.07 & 0.05 \\
\hline Ec_1 & 0.02 & 0.02 & 0.04 & 0.07 & 0.05 \\
\hline Ec_2 & 0.02 & 0.02 & 0.04 & 0.06 & 0.05 \\
\hline Ec_3 & 0.02 & 0.02 & 0.04 & 0.06 & 0.05 \\
\hline Ec_4 & 0.02 & 0.02 & 0.04 & 0.06 & 0.05 \\
\hline Ec_5 & 0.02 & 0.02 & 0.04 & 0.05 & 0.05 \\
\hline Ec_6 & 0.02 & 0.02 & 0.04 & 0.06 & 0.05 \\
\hline Ec_7 & 0.01 & 0.02 & 0.03 & 0.06 & 0.04 \\
\hline Ec_8 & 0.02 & 0.02 & 0.03 & 0.05 & 0.04 \\
\hline Ec_9 & 0.02 & 0.02 & 0.03 & 0.04 & 0.04 \\
\hline Ec_10 & 0.02 & 0.02 & 0.04 & 0.05 & 0.05 \\
\hline Ec_11 & 0.01 & 0.02 & 0.03 & 0.04 & 0.03 \\
\hline Ec_12 & 0.02 & 0.01 & 0.03 & 0.04 & 0.04 \\
\hline So_1 & 0.02 & 0.02 & 0.03 & 0.06 & 0.05 \\
\hline So_2 & 0.02 & 0.02 & 0.04 & 0.05 & 0.04 \\
\hline So_3 & 0.02 & 0.02 & 0.03 & 0.06 & 0.05 \\
\hline So_4 & 0.02 & 0.02 & 0.03 & 0.05 & 0.04 \\
\hline So_5 & 0.02 & 0.02 & 0.04 & 0.05 & 0.04 \\
\hline So_6 & 0.02 & 0.01 & 0.03 & 0.04 & 0.03 \\
\hline Ge_1 & 0.02 & 0.02 & 0.04 & 0.05 & 0.04 \\
\hline Ge_2 & 0.02 & 0.02 & 0.04 & 0.07 & 0.04 \\
\hline Ge_3 & 0.01 & 0.02 & 0.03 & 0.08 & 0.05 \\
\hline Ge_4 & 0.02 & 0.02 & 0.04 & 0.06 & 0.04 \\
\hline Ge_5 & 0.02 & 0.02 & 0.03 & 0.06 & 0.04 \\
\hline & & & & & \\
\hline
\end{tabular}

Following the steps of the TOPSIS method, Table 7 presents the ideal positive solution and the ideal negative solution. This information is necessary to calculate the values shown in Table 8, which correspond to the Euclidean distances of the ideal positive and negative solutions. Using Equation 8 presented in Figure 2, it was possible to calculate the $\mathrm{Ci}^{*}$ coefficient through which the ordering of goals will be performed. This coefficient is also shown in Table 8.

Table 7. Positive ideal solution and negative ideal solution for criteria access. Source: Authors.

\begin{tabular}{cccccc}
\hline Solution criteria & Group 1 & Group 2 & Group 3 & Group 4 & Group 5 \\
\hline $\begin{array}{c}\text { Positive ideal } \\
\text { solution (vj+) }\end{array}$ & 0.02 & 0.02 & 0.04 & 0.08 & 0.05 \\
$\begin{array}{c}\text { Negative ideal } \\
\text { solution (vj-) }\end{array}$ & 0.01 & 0.01 & 0.03 & 0.04 & 0.03 \\
\hline
\end{tabular}

Table 8. Positive ideal solution distance negative ideal solution distance, and coefficient Ci*. Source: Authors.

\begin{tabular}{cccc}
\hline Items & $\begin{array}{c}\text { Distances from the positive } \\
\text { ideal solution }(\mathbf{S i}+)\end{array}$ & $\begin{array}{c}\text { Distances from the } \\
\text { negative ideal solution (Si-) }\end{array}$ & $\begin{array}{c}\text { Coefficients } \\
(\mathbf{C i} \text { ) }\end{array}$ \\
\hline En_1 & 0.00 & 0.04 & 0.91 \\
En_2 & 0.00 & 0.05 & 0.92 \\
\hline
\end{tabular}




\begin{tabular}{|c|c|c|c|}
\hline En_3 & 0.01 & 0.04 & 0.81 \\
\hline En_4 & 0.01 & 0.04 & 0.86 \\
\hline En_5 & 0.01 & 0.04 & 0.79 \\
\hline En_6 & 0.01 & 0.04 & 0.78 \\
\hline En_7 & 0.01 & 0.04 & 0.77 \\
\hline En_8 & 0.01 & 0.04 & 0.79 \\
\hline En_9 & 0.01 & 0.04 & 0.80 \\
\hline En_10 & 0.01 & 0.04 & 0.80 \\
\hline Ec_1 & 0.01 & 0.04 & 0.89 \\
\hline Ec_2 & 0.01 & 0.03 & 0.69 \\
\hline Ec_3 & 0.01 & 0.03 & 0.68 \\
\hline Ec_4 & 0.02 & 0.03 & 0.56 \\
\hline Ec_5 & 0.02 & 0.03 & 0.52 \\
\hline Ec_6 & 0.02 & 0.03 & 0.56 \\
\hline Ec 7 & 0.02 & 0.03 & 0.58 \\
\hline Ec_-8 & 0.03 & 0.02 & 0.46 \\
\hline Ec_-9 & 0.04 & 0.01 & 0.26 \\
\hline Ec_10 & 0.02 & 0.02 & 0.49 \\
\hline Ec_11 & 0.04 & 0.01 & 0.20 \\
\hline Ec_12 & 0.04 & 0.01 & 0.11 \\
\hline So_t1 & 0.02 & 0.03 & 0.67 \\
\hline So_- 2 & 0.03 & 0.02 & 0.38 \\
\hline So_3 & 0.02 & 0.03 & 0.63 \\
\hline So_4 & 0.03 & 0.01 & 0.28 \\
\hline So_5 & 0.03 & 0.02 & 0.42 \\
\hline So_6 & 0.04 & 0.01 & 0.15 \\
\hline $\mathrm{Ge}^{-} \mathbf{1}$ & 0.03 & 0.02 & 0.35 \\
\hline $\mathrm{Ge}_{-} 2$ & 0.01 & 0.03 & 0.71 \\
\hline $\mathrm{Ge}^{-} 3$ & 0.01 & 0.04 & 0.80 \\
\hline $\mathrm{Ge}^{-} 4$ & 0.02 & 0.03 & 0.54 \\
\hline $\mathrm{Ge}^{-} 5$ & 0.02 & 0.02 & 0.52 \\
\hline
\end{tabular}

Finally, ranking the $\mathrm{Ci}^{*}$ coefficient values obtained, there is a comparative ranking of the indicators considered by the professionals in this sample to be the most relevant for the management and promotion of sustainable logistics systems. Table 9 presents the results of said ranking.

Table 9. Ranking of the items. Source: Authors.

\begin{tabular}{|c|c|c|}
\hline Position & $\left(\mathbf{C i}^{*}\right)$ & Items \\
\hline $\mathbf{1}^{\mathbf{0}}$ & 0.92 & En 2 - Analysis of adequacy regarding environmental policies \\
\hline $\mathbf{2}^{\mathbf{0}}$ & 0.91 & En_1 - Fuel consumption monitoring \\
\hline $\mathbf{3}^{\mathbf{0}}$ & 0.89 & Ec_1 - Mapping of operational logistics costs \\
\hline $4^{\circ}$ & 0.86 & En 4 - Control of energy consumption \\
\hline $5^{0}$ & 0.81 & En_3 - Transport environmental impact assessment \\
\hline $6^{0}$ & 0.80 & $\mathrm{Ge}_{-} 3$ - Number of suppliers that meet sustainability aspects \\
\hline $7^{\circ}$ & 0.80 & En_-9 - Elaboration and updating of environmental inventory \\
\hline $8^{\circ}$ & 0.80 & En_10 - Measurement of the amount of clean energy use \\
\hline $9^{\circ}$ & 0.79 & En_-8 - Monitoring of $\mathrm{CO} 2$ emission by developed logistics operation \\
\hline $10^{\circ}$ & 0.79 & En-5 - Measurement of total water consumption spent on logistics operations \\
\hline $11^{\circ}$ & 0.78 & En_6 - Amount of waste correctly destined \\
\hline $12^{\circ}$ & 0.77 & $\begin{array}{l}\text { En_-7 - Measurement of the amount of use of sustainable materials in logistics } \\
\text { operations }\end{array}$ \\
\hline $13^{\circ}$ & 0.71 & $\begin{array}{l}\text { Ge_2 - Assessment of the level of understanding of employees regarding } \\
\text { sustainability }\end{array}$ \\
\hline $14^{\circ}$ & 0.69 & Ec_2 - Measurement of the profitability of the logistics system \\
\hline $15^{\circ}$ & 0.68 & Ec_3 - Quality assessment of after care services \\
\hline $16^{\circ}$ & 0.67 & So 1 - Measurement of employee satisfaction in the workplace \\
\hline
\end{tabular}




\begin{tabular}{lll}
\hline $\mathbf{1 7}^{\circ}$ & 0.63 & $\begin{array}{c}\text { So_3 - Evaluation of occupational health and safety in the corporate } \\
\text { environment }\end{array}$ \\
$\mathbf{1 8}^{\circ}$ & 0.58 & Ec_7 - Distance traveled by total daily working time \\
$\mathbf{1 9}^{\circ}$ & 0.56 & Ec_6 - Total deliveries served per day \\
$\mathbf{2 0}^{\circ}$ & 0.56 & Ec_4 - Average journey time per delivery \\
$\mathbf{2 1}^{\circ}$ & 0.54 & Ge_4 - Frequency of publishing sustainability reports \\
$\mathbf{2 2}^{\circ}$ & 0.52 & Ec_5 - Delivery reliability assessment \\
$\mathbf{2 3}^{\circ}$ & 0.52 & Ge_5 - Analysis of the customer's perception of the logistics process \\
$\mathbf{2 4}^{\circ}$ & 0.49 & Ec_10 - Rate of filling capacity of means of transport \\
$\mathbf{2 5}^{\circ}$ & 0.46 & Ec_8 - Evaluation of order fulfillment time \\
$\mathbf{2 6}^{\circ}$ & 0.42 & So_5 - Participatory management index \\
$\mathbf{2 7}^{\circ}$ & 0.38 & So_2 - Monitoring the impacts of operations on neighboring communities \\
$\mathbf{2 8}^{\circ}$ & 0.35 & Ge_1 - Assessment of long-term strategic objectives \\
$\mathbf{2 9}^{\circ}$ & 0.28 & So_4 - Social demands employability index \\
$\mathbf{3 0}^{\circ}$ & 0.26 & Ec_9 - Evaluation of the corporate image of the logistics system \\
$\mathbf{3 1}^{\circ}$ & 0.20 & Ec_11 - Freight quantity fluctuation analysis \\
$\mathbf{3 2}^{\circ}$ & 0.15 & So_6 - Satisfaction rate of inhabitants of neighboring communities \\
$\mathbf{3 3}^{\circ}$ & 0.11 & Ec_12 - Mapping of information sharing costs \\
\hline
\end{tabular}

In order to guarantee the significance of results and achievement of the objective proposed in this study, a detailed analysis of the ranking generated by handling the survey data using the TOPSIS method was carried out in detail. Such analysis considered the positions of indicators in the ranking and their classification according to the area of TBL to which each belongs. In addition, the results are discussed in the light of literature.

When analyzing the first ten best ranked indicators, it is noticeable that none of them are inserted in the context of social aspects; eight of them are related to environmental aspects, one to economic aspects and one classified as general. Some indicators related to environmental aspects; however, they are also related to economic benefits. As an example, "monitoring fuel consumption" reduces environmental impacts, while providing cost savings. It is worth mentioning that the first indicator best classified in social aspects with regards to the "Measurement of employee satisfaction in the workplace" occupies the 16th position. Furthermore, four of the six social indicators are among the ten worst ranked. This pattern reinforces the apparent issue related to the perception that social aspects are delegated to secondary hierarchy levels by Brazilian professionals when considering sustainability in logistics activities.

Agrawal and Singh (2019) emphasize that the logistics sector is not only a significant contributor to economic performance and international development, but also plays a vital role in environmental and social aspects. The scenario identified in this study is worrying because, according to Uyar et al., (2020), the logistics sector plays an important role towards social aspects. Agyabeng-Mensah et al., (2020) highlight that the adoption of sustainable practices in the management of logistics systems still have little influence on improving social well-being, health of society and employees. This can be explained by the need to better understand the comprehensive sustainability perspectives in the context of logistics systems (Uyar et al., 2020).

Considering economic aspects, Khan et al. (2019) present the importance of logistics sector for to improve countries' economic performance The authors highlight the improvement of global supply chain operations and industrialization operations. From environmental aspects perspective, Sim and Sim, (2017) highlight the great negative environmental impact caused by 
logistical operations and argue about the importance of adopting management strategies that allow to minimize this negative impact generated by logistical systems. In this sense, some actions with practical managerial implications are presented, mainly to meet the needs of logistics managers in developing economies, such as Latin American countries. To improve this scenario, Martins et al. (2019) and Frayret et al. (2017) highlight the need to develop assessment models that consider the three pillars of sustainability (environmental, economic and social) in logistics systems.

\section{Conclusions}

Based on the results presented, it is concluded that the main objective proposed in this study was achieved, since it was possible to identify the comparative importance that Brazilian professionals who act with logistics activities attribute to different indicators regarding sustainability. A set of 33 indicators was used to develop a research instrument and used in a survey with 50 professionals.

The main conclusion obtained is that, despite considering social indicators for the management and promotion of sustainability in logistical systems, Brazilian professionals relegate them to a secondary level when compared with environmental indicators. This proves the hypothesis presented in the introductory section.

Regarding the limitations of this study, it is important to mention the sample size (50 respondents) and some considerations adopted; however, we highlight again the exploratory nature of this study. We intended, with this study, to amplify the debates about how sustainability is perceived and motivates other researchers. In addition to the theoretical contributions that allow the expansion of debates in the area, this study also have practical implications, especially as a guidance for policy makers. This paper has strong implications for theory and practice, since it links the principles of sustainable development with the field of logistics. The results obtained may be used to support teaching programs related to business courses and also can help to identify specific policies to support the competitiveness of local players, suggesting the development of specific sustainable capacities that can contribute to operational competitiveness, the company's reputation and the sustainable performance of companies operating in the logistics sector. We believe that these actions in logistics sector management can contribute considerably to the mentioned improvements, especially in emerging markets, as is the case in Latin America.

Finally, the results presented here can contribute to the development of new models and tools that enable better performance of the logistics systems in terms of meeting sustainability considering the three aspects of the TBL.

\section{References}

Abbasi, M. and Nilsson, F. (2016), "Developing environmentally sustainable logistics Exploring themes and challenges from a logistics service providers' perspective", Transportation Research Part D: Transport and Environment, Elsevier Ltd, Vol. 46, pp. 273-283. 
Abedini, A., Li, W., Badurdeen, F. and Jawahir, I.S. (2020), "A metric-based framework for sustainable production scheduling", Journal of Manufacturing Systems, Elsevier, Vol. 54 No. May 2019, pp. 174-185.

Agrawal, S. and Singh, R.K. (2019), "Analyzing disposition decisions for sustainable reverse logistics: Triple Bottom Line approach”, Resources, Conservation and Recycling, Elsevier, Vol. 150 No. August, p. 104448.

Agyabeng-Mensah, Y., Afum, E. and Ahenkorah, E. (2020), "Exploring financial performance and green logistics management practices: Examining the mediating influences of market, environmental and social performances", Journal of Cleaner Production, Elsevier Ltd, p. 120613.

Ahmad, S., Wong, K.Y. and Rajoo, S. (2019), "Sustainability indicators for manufacturing sectors: A literature survey and maturity analysis from the triple-bottom line perspective”, Journal of Manufacturing Technology Management, Vol. 30 No. 2, pp. $312-334$.

Aldakhil, A.M., Nassani, A.A., Awan, U., Abro, M.M.Q. and Zaman, K. (2018), "Determinants of green logistics in BRICS countries: An integrated supply chain model for green business", Journal of Cleaner Production, Elsevier Ltd, Vol. 195, pp. 861-868.

ALVES, A.P.F. and NASCIMENTO, L.F.M. DO. (2014), "Green Supply Chain: a protagonist or a supporting role in Brazil?", Revista de Administração de Empresas, Vol. 54 No. 5 , pp. 510-520.

Arbolino, R., Boffardi, R. and Ioppolo, G. (2019), "The effectiveness of European energy policy on the Italian system: Regional evidences from a hierarchical cluster analysis approach”, Energy Policy, Elsevier Ltd, Vol. 132 No. December 2018, pp. 47-61.

Asmone, A.S., Conejos, S. and Chew, M.Y.L. (2019), "Green maintainability performance indicators for highly sustainable and maintainable buildings", Building and Environment, Elsevier Ltd, Vol. 163, p. 106315.

Ballou, R.H. (2004), Business Logistics/Supply Chain Management: Planning, Organizing and Controlling the Supply Chain, 5th Editio., Pearson/Prentice Hall Inc., New Jersey.

Bebbington, J. and Thomson, I. (2013), "Sustainable development, management and accounting: Boundary crossing", Management Accounting Research, Vol. 24 No. 4, pp. $277-283$.

Björklund, M. and Forslund, H. (2018), "Exploring the sustainable logistics innovation process", Industrial Management and Data Systems, Vol. 118 No. 1, pp. 204-217.

Björklund, M., Forslund, H. and Persdotter Isaksson, M. (2016), "Exploring logistics-related environmental sustainability in large retailers", International Journal of Retail \& Distribution Management, Vol. 44 No. 1, pp. 38-57.

Bloemhof, J.M., van der Vorst, J.G.A.J., Bastl, M. and Allaoui, H. (2015a), "Sustainability assessment of food chain logistics", International Journal of Logistics Research and Applications, Vol. 18 No. 2, pp. 101-117.

Bloemhof, J.M., van der Vorst, J.G.A.J., Bastl, M. and Allaoui, H. (2015b), "Sustainability assessment of food chain logistics", International Journal of Logistics Research and 
Applications, Vol. 18 No. 2, pp. 101-117.

Brundtland, G.H. (1987), "Our Common Future: Report of the World Commission on Environment and Development”, United Nations Commission, Vol. 4 No. 1, p. 300.

Buldeo Rai, H., van Lier, T., Meers, D. and Macharis, C. (2018), "An indicator approach to sustainable urban freight transport", Journal of Urbanism: International Research on Placemaking and Urban Sustainability, Routledge, Vol. 11 No. 1, pp. 81-102.

Calabrese, A., Castaldi, C., Forte, G. and Levialdi, N.G. (2018), "Sustainability-oriented service innovation: An emerging research field", Journal of Cleaner Production, Elsevier Ltd, Vol. 193, pp. 533-548.

Carlucci, F., Cirà, A., Ioppolo, G., Massari, S. and Siviero, L. (2018), "Logistics and land use planning: An application of the ACIT indicator in European port regions", Land Use Policy, Elsevier, Vol. 75 No. March, pp. 60-69.

Chae, B. (Kevin). (2009), "Developing key performance indicators for supply chain: an industry perspective", Supply Chain Management: An International Journal, Vol. 14 No. 6, pp. 422-428.

Chakraborty, S., Sharma, A. and Vaidya, O.S. (2020), “Achieving sustainable operational excellence through IT implementation in Indian logistics sector: An analysis of barriers", Resources, Conservation and Recycling, Vol. 152 No. September 2019, p. 104506.

Chandra, D. and Kumar, D. (2019), "Two-way assessment of key performance indicators to vaccine supply chain system in India”, International Journal of Productivity and Performance Management, Vol. 68 No. 1, pp. 194-230.

Chen, C.-S., Yu, C.-C. and Hu, J.-S. (2018), "Constructing performance measurement indicators to suggested corporate environmental responsibility framework", Technological Forecasting and Social Change, Elsevier, Vol. 135 No. May 2017, pp. 33-43.

Chen, Z. and Bidanda, B. (2019), "Sustainable manufacturing production-inventory decision of multiple factories with JIT logistics, component recovery and emission control", Transportation Research Part E: Logistics and Transportation Review, Elsevier, Vol. 128 No. October 2018, pp. 356-383.

Chen, Z. and Pak, M. (2017), "A Delphi analysis on green performance evaluation indices for ports in China", Maritime Policy \& Management, Routledge, Vol. 44 No. 5, pp. 537550.

Chhabra, D., Garg, S.K. and Singh, R.K. (2018), “Analyzing alternatives for green logistics in an Indian automotive organization: A case study", Journal of Cleaner Production, Elsevier Ltd, Vol. 167, pp. 962-969.

Christmann, A. and Van Aelst, S. (2006), "Robust estimation of Cronbach's alpha", Journal of Multivariate Analysis, Vol. 97 No. 7, pp. 1660-1674.

Chu, Z., Wang, L. and Lai, F. (2019), "Customer pressure and green innovations at third party logistics providers in China", The International Journal of Logistics Management, Vol. 30 No. 1, pp. 57-75. 
Dahlmann, F. and Röhrich, J.K. (2019), "Sustainable supply chain management and partner engagement to manage climate change information", Business Strategy and the Environment, No. September, p. bse.2392.

Dang, V.L. and Yeo, G.T. (2018), "Weighing the Key Factors to Improve Vietnam's Logistics System", The Asian Journal of Shipping and Logistics, Elsevier B.V., Vol. 34 No. 4, pp. 308-316.

Davis-Sramek, B., Robinson, J.L., Darby, J.L. and Thomas, R.W. (2020), "Exploring the differential roles of environmental and social sustainability in carrier selection decisions", International Journal of Production Economics, Elsevier B.V., Vol. 227 No. December 2019, p. 107660.

Denyer, D., Tranfield, D. (2009), "Producing a systematic review.", Organ. Res. Methods, available at:https://doi.org/https://doi.org/10.1080/03634528709378635.

El-Berishy, N., Rügge, I. and Scholz-Reiter, B. (2013), The Interrelation between Sustainability and Green Logistics, IFAC Proceedings Volumes (IFAC-PapersOnline), Vol. 6, IFAC, available at:https://doi.org/10.3182/20130911-3-BR-3021.00067.

Eroglu, C., Kurt, A.C. and Elwakil, O.S. (2016), "Stock Market Reaction to Quality, Safety, and Sustainability Awards in Logistics", Journal of Business Logistics, Vol. 37 No. 4, pp. 329-345.

Frayret, J., Furtado, P., Conference, M., Nathanail, E., Adamos, G., Gogas, M., Adamos, G., et al. (2017), "A generic planning approach for sustainable supply chain management How to integrate concepts and methods to address the issues of sustainability?", Journal of Cleaner Production, Elsevier Ltd, Vol. 153 No. 4, pp. 146-163.

Golroudbary, S.R., Zahraee, S.M., Awan, U. and Kraslawski, A. (2019), "Sustainable operations management in logistics using simulations and modelling: A framework for decision making in delivery management", Procedia Manufacturing, Elsevier B.V., Vol. 30, pp. 627-634.

Govindan, K., Garg, K., Gupta, S. and Jha, P.C. (2016), "Effect of product recovery and sustainability enhancing indicators on the location selection of manufacturing facility", Ecological Indicators, Elsevier Ltd, Vol. 67, pp. 517-532.

Gruchmann, T., Schmidt, I., Lubjuhn, S., Seuring, S. and Bouman, M. (2019), "Informing logistics social responsibility from a consumer-choice-centered perspective", International Journal of Logistics Management, Vol. 30 No. 1, pp. 96-116.

Helo, P. and Ala-Harja, H. (2018), "Green logistics in food distribution - a case study", International Journal of Logistics Research and Applications, Vol. 21 No. 4, pp. 464479.

Hisano Barbosa, D. and Andreotti Musetti, M. (2010), "Logistics information systems adoption: an empirical investigation in Brazil", Industrial Management \& Data Systems, Vol. 110 No. 6, pp. 787-804.

Hojnik, J., Biloslavo, R., Cicero, L. and Cagnina, M.R. (2020), "Sustainability indicators for the yachting industry: Empirical conceptualization", Journal of Cleaner Production, Elsevier Ltd, Vol. 249, p. 119368. 
Hong, J., Alzaman, C., Diabat, A. and Bulgak, A. (2018), "Sustainability dimensions and PM 2.5 in supply chain logistics", Annals of Operations Research, Springer US, available at:https://doi.org/10.1007/s10479-018-3077-7.

Irfani, D.P., Wibisono, D. and Basri, M.H. (2019a), "Design of a logistics performance management system based on the system dynamics model", Measuring Business Excellence, Vol. 23 No. 3, pp. 269-291.

Irfani, D.P., Wibisono, D. and Basri, M.H. (2019b), "Logistics performance measurement framework for companies with multiple roles", Measuring Business Excellence, Vol. 23 No. 2, pp. 93-109.

Jamali, M.-B. and Rasti-Barzoki, M. (2019), “A game theoretic approach to investigate the effects of third-party logistics in a sustainable supply chain by reducing delivery time and carbon emissions", Journal of Cleaner Production, Elsevier Ltd, Vol. 235, pp. 636652.

Jozef, E., Kumar, K.M., Iranmanesh, M. and Foroughi, B. (2019), "The effect of green shipping practices on multinational companies' loyalty in Malaysia”, The International Journal of Logistics Management, Vol. 30 No. 4, pp. 974-993.

Kalenoja, H., Kallionpää, E. and Rantala, J. (2011), "Indicators of energy efficiency of supply chains", International Journal of Logistics Research and Applications, Vol. 14 No. 2, pp. 77-95.

Khan, S.A.R., Jian, C., Zhang, Y., Golpîra, H., Kumar, A. and Sharif, A. (2019), "Environmental, social and economic growth indicators spur logistics performance: From the perspective of South Asian Association for Regional Cooperation countries", Journal of Cleaner Production, Vol. 214, pp. 1011-1023.

Khan, S.A.R. and Qianli, D. (2017), "Does national scale economic and environmental indicators spur logistics performance? Evidence from UK", Environmental Science and Pollution Research, Environmental Science and Pollution Research, Vol. 24 No. 34, pp. 26692-26705.

Khan, S.A.R., Qianli, D., SongBo, W., Zaman, K. and Zhang, Y. (2017), "Environmental logistics performance indicators affecting per capita income and sectoral growth: evidence from a panel of selected global ranked logistics countries", Environmental Science and Pollution Research, Environmental Science and Pollution Research, Vol. 24 No. 2, pp. 1518-1531.

Kumar, A. and Anbanandam, R. (2020), "Location selection of multimodal freight terminal under STEEP sustainability", Research in Transportation Business and Management, Elsevier, Vol. 33 No. July 2019, p. 100434.

Kunadhamraks, P. and Hanaoka, S. (2008), "Evaluating the logistics performance of intermodal transportation in Thailand", Asia Pacific Journal of Marketing and Logistics, Vol. 20 No. 3, pp. 323-342.

Kuo, T.-C., Chiu, M.-C., Chung, W.-H. and Yang, T.-I. (2019), “The circular economy of LCD panel shipping in a packaging logistics system", Resources, Conservation and Recycling, Elsevier, Vol. 149 No. November 2018, pp. 435-444.

Lan, S. and Tseng, M.-L. (2018), “Coordinated Development of Metropolitan Logistics and 
Economy Toward Sustainability", Computational Economics, Springer US, Vol. 52 No. 4, pp. 1113-1138.

Lan, S.L. and Zhong, R.Y. (2018), "Coordinated development between metropolitan economy and logistics for sustainability", Resources, Conservation and Recycling, Elsevier B.V., Vol. 128, pp. 345-354.

Le, F., Olivier, B. and Mognol, J.H.P. (2013), "Sustainable manufacturing : evaluation and modeling of environmental impacts in additive manufacturing", pp. 1927-1939.

Lee, K.-H. and Farzipoor Saen, R. (2012), "Measuring corporate sustainability management: A data envelopment analysis approach", International Journal of Production Economics, Elsevier, Vol. 140 No. 1, pp. 219-226.

Lee, K.-H. and Kim, J.-W. (2011), "Integrating Suppliers into Green Product Innovation Development: an Empirical Case Study in the Semiconductor Industry", Business Strategy and the Environment, Vol. 20 No. 8, pp. 527-538.

Lee, K.-H. and Wu, Y. (2014), "Integrating sustainability performance measurement into logistics and supply networks: A multi-methodological approach", The British Accounting Review, Elsevier Ltd, Vol. 46 No. 4, pp. 361-378.

Liu, J., Yuan, C., Hafeez, M. and Yuan, Q. (2018), “The relationship between environment and logistics performance : Evidence from Asian countries", Journal of Cleaner Production, Elsevier Ltd, Vol. 204, pp. 282-291.

Malhotra, N.K. (2012), Pesquisa de Marketing, Bookman., Porto Alegre, RS, Brasil.

Martins, V., Anholon, R., Quelhas, O.L.G. and Filho, W. (2019), "Sustainable Practices in Logistics Systems: An Overview of Companies in Brazil", Sustainability, Vol. 11 No. 15, p. 4140.

Melkonyan, A., Gruchmann, T., Lohmar, F., Kamath, V. and Spinler, S. (2020), "Sustainability assessment of last-mile logistics and distribution strategies: The case of local food networks", International Journal of Production Economics, Elsevier B.V., Vol. 228 No. July 2019, p. 107746.

Micale, R., Marannano, G., Giallanza, A., Miglietta, P.P., Agnusdei, G.P. and La Scalia, G. (2019), "Sustainable vehicle routing based on firefly algorithm and TOPSIS methodology”, Sustainable Futures, Elsevier Ltd, Vol. 1 No. September, p. 100001.

Moon, D.S., Kim, D.J. and Lee, E.K. (2015), “A study on competitiveness of sea transport by comparing international transport routes between Korea and EU", Asian Journal of Shipping and Logistics, Elsevier B.V., Vol. 31 No. 1, pp. 1-20.

Morana, J. and Gonzalez-Feliu, J. (2015), “A sustainable urban logistics dashboard from the perspective of a group of operational managers", edited by Hamid Allaoui ,Dr. Alok Choudhary, P.Management Research Review, Vol. 38 No. 10, pp. 1068-1085.

Narayana, S.A., Pati, R.K. and Padhi, S.S. (2019), "Market dynamics and reverse logistics for sustainability in the Indian Pharmaceuticals industry", Journal of Cleaner Production, Elsevier Ltd, Vol. 208, pp. 968-987.

Nikolaou, I.E., Evangelinos, K.I. and Allan, S. (2013), “A reverse logistics social 
responsibility evaluation framework based on the triple bottom line approach", Journal of Cleaner Production, Elsevier Ltd, Vol. 56, pp. 173-184.

Nilsson, F.R. (2019), “A complexity perspective on logistics management”, The International Journal of Logistics Management, Vol. 30 No. 3, pp. 681-698.

Penteado Pinto Martins, P., Maurício Gama Boaventura, J., Americo Fischmann, A., Kramer Costa, B. and Giovinazzo Spers, R. (2012), "Scenarios for the Brazilian road freight transport industry", Foresight, Vol. 14 No. 3, pp. 207-224.

Pereira, C.M., Anholon, R., Rampasso, I.S., Quelhas, O.L.G., Leal Filho, W. and SantaEulalia, L.A. (2020), "Evaluation of lean practices in warehouses: an analysis of Brazilian reality", International Journal of Productivity and Performance Management, available at:https://doi.org/10.1108/IJPPM-01-2019-0034.

Pilouk, S. and Koottatep, T. (2017), "Environmental performance indicators as the key for eco-industrial parks in Thailand", Journal of Cleaner Production, Elsevier Ltd, Vol. 156, pp. 614-623.

Rai, H.B., Lier, T. Van, Meers, D. and Macharis, C. (2018), “An indicator approach to sustainable urban freight transport", Journal of Urbanism: International Research on Placemaking and Urban Sustainability, Routledge, Vol. 9175, pp. 1-22.

Rashidi, K. and Cullinane, K. (2019), "Evaluating the sustainability of national logistics performance using Data Envelopment Analysis", Transport Policy, Elsevier Ltd, Vol. 74 No. November 2018, pp. 35-46.

Routroy, S. and Pradhan, S.K. (2014), "Analyzing the performance of supplier development: a case study”, International Journal of Productivity and Performance Management, Vol. 63 No. 2, pp. 209-233.

Sarraj, R., Ballot, E., Pan, S., Hakimi, D. and Montreuil, B. (2014), "Interconnected logistic networks and protocols: simulation-based efficiency assessment", International Journal of Production Research, Vol. 52 No. 11, pp. 3185-3208.

Schaltegger, S. and Burritt, R. (2014), "Measuring and managing sustainability performance of supply chains: Review and sustainability supply chain management framework", Supply Chain Management: An International Journal, Vol. 19 No. 3, pp. 232-241.

Schulz, S.F. and Heigh, I. (2009), "Logistics performance management in action within a humanitarian organization", edited by Tatham, P.H.Management Research News, Vol. 32 No. 11, pp. 1038-1049.

Seguí, X., Puig, M., Quintieri, E., Wooldridge, C. and Darbra, R.M. (2016), "New environmental performance baseline for inland ports: A benchmark for the European inland port sector", Environmental Science \& Policy, Elsevier Ltd, Vol. 58, pp. 29-40.

Seuring, S. and Müller, M. (2008), "From a literature review to a conceptual framework for sustainable supply chain management", Journal of Cleaner Production, Vol. 16 No. 15, pp. 1699-1710.

Sim, J. and Sim, J. (2017), “Air emission and environmental impact assessment of Korean automotive logistics", Journal of Cleaner Production, Elsevier Ltd, Vol. 159, pp. 130140. 
Singh, R.K., Gupta, A., Kumar, A. and Khan, T.A. (2016), "Ranking of barriers for effective maintenance by using TOPSIS approach", Journal of Quality in Maintenance Engineering, Vol. 22 No. 1, pp. 18-34.

Sirilertsuwan, P., Ekwall, D. and Hjelmgren, D. (2018), "Proximity manufacturing for enhancing clothing supply chain sustainability", available at:https://doi.org/10.1108/IJLM-09-2017-0233.

Stindt, D. (2017), “A generic planning approach for sustainable supply chain management How to integrate concepts and methods to address the issues of sustainability?", Journal of Cleaner Production, Elsevier Ltd, Vol. 153, pp. 146-163.

Torabizadeh, M., Yusof, N.M., Ma'aram, A. and Shaharoun, A.M. (2020), “Identifying sustainable warehouse management system indicators and proposing new weighting method”, Journal of Cleaner Production, Elsevier Ltd, Vol. 248, p. 119190.

Tseng, M.L., Wu, K.J., Chiu, A.S., Lim, M.K. and Tan, K. (2018), "Service innovation in sustainable product service systems: Improving performance under linguistic preferences", International Journal of Production Economics, Elsevier B.V., Vol. 203 No. July, pp. 414-425.

Uyar, A., Karaman, A.S. and Kilic, M. (2020), "Is corporate social responsibility reporting a tool of signaling or greenwashing? Evidence from the worldwide logistics sector", Journal of Cleaner Production, Elsevier Ltd, Vol. 253, p. 119997.

Velasco, N., Moreno, J.P. and Rebolledo, C. (2018), "Logistics practices in healthcare organizations in Bogota", Academia Revista Latinoamericana de Administracion, Vol. 31 No. 3, pp. 519-533.

Watanabe, E.H., Silva, R.M. da, Blos, M.F., Junqueira, F., Filho, D.J.S. and Miyagi, P.E. (2018), "Framework to evaluate the performance and sustainability of a disperse productive system", Journal of the Brazilian Society of Mechanical Sciences and Engineering, Springer Berlin Heidelberg, Vol. 40 No. 6, pp. 1-27.

Xavier, A.F., Naveiro, R.M., Aoussat, A. and Reyes, T. (2017), "Systematic literature review of eco-innovation models: Opportunities and recommendations for future research", Journal of Cleaner Production, Vol. 149, pp. 1278-1302.

Yun, G., Yalcin, M.G., Hales, D.N. and Kwon, H.Y. (2019), "Interactions in sustainable supply chain management : a framework review", The International Journal of Logistics Management, available at:https://doi.org/10.1108/IJLM-05-2017-0112.

Zaman, K. and Shamsuddin, S. (2017), "Green logistics and national scale economic indicators: Evidence from a panel of selected European countries", Journal of Cleaner Production, Elsevier Ltd, Vol. 143, pp. 51-63.

Zhao, X., Ke, Y., Zuo, J., Xiong, W. and Wu, P. (2020), "Evaluation of sustainable transport research in 2000-2019", Journal of Cleaner Production, Elsevier Ltd, Vol. 256, p. 120404. 